\title{
Galampa as Public Space on Fishermen Societies in Holimombo Jaya Village on Eastern Coast of Buton Island
}

\author{
$1^{\text {st }}$ Ahmadin \\ Departement of History Education \\ Faculty of Social Science \\ Universitas Negeri Makassar \\ Makassar, Indonesia \\ ahmadin@unm.ac.id
}

\author{
$2^{\text {nd }}$ Amiruddin \\ Faculty of Social Science \\ Universitas Negeri Makassar \\ Makassar, Indonesia \\ Amiruddin6022@unm.ac.id
}

\begin{abstract}
Public space not only belongs to modern society in urban areas, but also has become part of the pattern of life in rural communities including fishermen living in coastal areas. Compared to urban public spaces of a general and impermanent nature, in the village there exists a fixed place and possesses certain sacred values. This paper examines the Galampa as a public space for fishing communities in Holimombo Jaya Village on the Eastern Coast of Buton Island. Galampa as a public space is a representation of the world that is always adjacent and located in the east of the mosque. This public space is a space or community meeting hall to discuss various matters relating to social, economic, and cultural activities of the community. In its history, the effective Galamba functioned in the social life of the local community in Buton, drawing on the concept of public space discussed by Habermas. The study focuses on the function and role of Galampa in the social, cultural, and economic life of the community and the implication of the institution's presence in solving various problems.
\end{abstract}

Keywords-Galampa, Public Space, Fisherman's
Community.

\section{INTRODUCTION}

The study of public space has so far been linked to urban communities and is still focused on modern humans [1]-[5]. Whereas historically among the traditional community or indigenous unity in various regions in Indonesia has long had a public space with a variety of names and terms used. Even public spaces are proving effective as a space of democracy to convey the aspirations of society [6]-[11].

This paper describes the Galampa as a public space in the fishing community in Holimombo Jaya Village located in Pasarwajo District, Buton Regency, Southeast Sulawesi. This residential community center was a combination of Tolalo Holimombo Village and then it was exposed in 1980. At that time there was no village head yet. In 1999 there was only the first village chief who served the government for 13 years, namely Alirah. In carrying out his function as head of the village level government, Alirah was accompanied by the secretary of the village of La Sirabah appointed directly by the subdistrict at that time [12].

The inhabitants of this village earn $80 \%$ of their income as fishermen and $20 \%$ as farmers. According to the local village chief, before the entry of companies using trawling tiger as one method in fishing in the village fishermen income can reach Rp 600.000-700.000/hari. However, after modern fishermen with advanced technological devices, led to socio-economic changes in the village community. This is particularly the case since the operation of this type of fish trawler in the waters of Buton [13].

Social dynamics in society always shows changes in various aspects of life, including patterns of relationships between individuals in a space. Similarly, the fishing communities that inhabit the coastal areas, also experienced changes in social relations patterns that are characteristic of each picture, including among the fishermen community in the village of Holimombo Jaya. Nevertheless, one interesting thing about the social life of the community in this village is the functioning of traditional council and the enactment of customary law in solving various problems that arise in everyday life.

A public space called Galampa has long been present and become an integral part of the journey of history of social life of Holimombo Jaya Village community. Galampa as a public space is a representation of the world that is always adjacent and located in the east of the mosque. This public space is a space or community meeting hall to discuss various matters relating to social, economic, and cultural activities of the community.

Still functioning effectively this Galampa in the social life of society, interestingly connected with the concept of public space discussed [14]-[16]. The author of the book "The Structural Tranformation of the Public Sphare", explains that public space is a conditioned space in such a way that allows citizens to articulate interests in order to form opinions and wills together [17]-[20].

If Habermas considers public space as a medium that bridges the public and the State's interests on the basis of democratic principles, then the function of Galampa as a public space in Holimombo Jaya Village is like that. Thus, the main question posed in relation to the existence of Galampa is how the function and position in society and social implications on the survival of society. 


\section{RESEARCH METHODS}

The location of this research is Holimombo Jaya Village, Pasarwajo District, Buton Regency, Southeast Sulawesi. There are several considerations in choosing this location, including: (1) although there have been many writings on fisherman activities in Buton, but studies of coastal communities in relation to public space are still lacking; (2) in terms of social and cultural life, customary law is very powerful in that area. Target and focus of this research, namely fishermen in the village of Holimombo Jaya.

This type of research is qualitative which produces descriptive data in the form of narrative and oral obtained from informants or in the form of observed behavior [10]. In its implementation, this research can also be called naturalistic research that examines the condition of objects naturally. This research approach focuses on the individual background as a whole, without positioning the individual or organization into a particular variable or hypothesis. In other words, making the individual or organization as a whole as a whole [21]-[23].

As qualitative research, what is observed are a number of general principles that form the basis for the realization of the symptoms in social life. The important thing analyzed in this study is not the variables but the relationship between the general principles of a phenomenon related to the culture of the community under study. The results of the analysis of the relationship between the symptoms, then analyzed using theories. The research problem was analyzed using a synchronous and diachronic approach. The first approach is intended to examine certain aspects as part of an object, the symptoms and ideas that develop over time. On the other hand the second approach is used to examine the relationship between various aspects of social life in a certain period of time[24]-[26].

A number of informants intended in this study are individuals or families who live and fulfill their needs in coastal areas. In addition, people who have knowledge of the maritime culture and local wisdom of the Buton Community. There are 3 types of informants in this study, namely key informants, expert informants, and ordinary informants. The selection of informants in this study was not done randomly but purposively. In order to obtain better data validity, cross-check information was also obtained on several informants who were likely to find different perceptions or realities in the field.

There are three stages of the data collection process in this study, namely: (1) observation, in the form of a systematic observation and recording of a number of symptoms based on the purpose of the research conducted, (2) an interview, in the form of a question and answer process conducted orally, for example between two people or more directly, and (3) documentation, in the form of searching for data by utilizing a number of documents.

To expedite the process of data collection and management in this research, several research instruments are used as follows: (1) observation forms, in the form of notes containing important points of research topics and problems. This observation was carried out by utilizing guidelines in the form of instruments to observe the social environment of fishing settlements from various aspects. Even in this process, observations of written evidence are carried out in accordance with the research topic; (2) Guidelines for interviews, list the main questions for informants. This instrument, in addition to containing a list of questions, also contains brief answer items prepared as an answer choice from the informant. In the process of collecting data, a series of in-depth interviews were conducted, referring to guide interviews in the form of questionnaires, which were questions that sought to explore various answers in depth from the informants regarding the topic or theme of the research; (3) Documentary, in the form of a written record of a number of important archives that are related to the social problems studied.

As a descriptive research, the data produced in this process is qualitative data. It should be noted that this research approach was chosen in relation to the specific characteristics of a social and cultural phenomenon of the local community. The data analysis process in this study was carried out in line with the time of research activities. This means that the data analysis process is carried out simultaneously with the time of the research, especially when certain data is considered relevant. The process is carried out in the form of analysis at the level of data reduction with a descriptive analysis model.

\section{RESULTS AND DISCUSSION}

\section{A. Function and Position Galampa}

Galampa is public space Holimombo Jaya Village community which is a representation of the world that is always adjacent and located in the east of the mosque. This galampa is a space or community meeting hall to discuss matters relating to social, economic, and cultural activities of the community.

According to Holimobo Village, indigenous peoples in this village from the very beginning of their existence made Galampa a place to discuss land issues or disputes, types of fines for liquor drinkers, timing of pioneering or starting gardening, planting season determination, and others related to common interests community members .

It is simply illustrated that all indigenous communities (customary unions) within the administrative territory of Pasarwajo Sub-district and other sub-districts each have their own Galampas. Thus, each society in one adat unit resolves its own social, cultural, and economic problems through their Galampas. One interesting thing about the function of Galampa as a social space is every meeting or meeting led by traditional chairman who in the local language call this Parabela, imam mosque also present follow this custom procession. Conversely, every meeting held at the mosque relates to religious social issues, Parabela (adat chief) is also present together [27].

The process of discussing important matters concerning the mundane issue in Galampa goes very uniquely in which the residents who are present sit on the floor extending on all 
sides of the building space and letting in the middle of the blank. Even the interesting thing from the meeting hall or public space is not using the wall and let it open. Citizens with customary councils sitting in discussing important issues in people's lives, can be seen from outside Galampa. This according to the local community is a sign that their activities are open and accessible or witnessed by all parties.

This at the same time is proof that in the relationship between the government and the people, there is always an open relationship that reflects democratic principles. The local community acknowledges that the application of customary rules and the application of law to violations committed by someone in this area, is always resolved in an open manner. Thus, a harmonious relationship between all elements of society is always interwoven.

\section{B. Implications for the existence of Galampa}

Holimombo Jaya Village is very important and has functioned effectively as a public space which serves as a means of conveying aspirations and solving various social, cultural and economic problems as well as cases related to the law. A number of sanctions imposed by adat councils against perpetrators who violate the rules prevailing in society, proved to provide a deterrent effect that serves as a mechanism of social control.

For example, drinkers of wine caught and undergoing indigenous congregations in Galampa not only suffered material harm in the form of a fine amount to be paid millions, but also socially sanctioned. How not to go through an open customary court and witnessed by many people psychologically raises the shame for the suspect. This condition also applies to the party or someone who commits the act of theft and must undergo a customary session led by Parabela[28]. If it turns out in a session that was attended by residents of this Holimombo Village.

The process of solving social and cultural problems in the Buton community through an open session in a public space called Galampa, is a heavy social sanction. This is intended, namely before the customary parties determine penalties for lawbreakers, the process of public humiliation through this open meeting is actually a social sanction

\section{CONCLUSION}

In the social life of the fishermen community of Holimombo Jaya Village, Pasarwajo Subdistrict, Galampa as a public space has an important position and role as a venue to voice aspirations for the people. Similarly, Galamba serves as a public space in which to solve social, economic, and cultural problems through deliberations mediated by a customary leader named Parabela. So far, many social issues have been discussed in this public space, such as crime cases, theft of fish, drinking of wine, and other types of crimes. Thus, Galampa remains functioning as a public space or a democratic space, then the social life of fishing communities in Holimombo Village live safely and peacefully in togetherness.

\section{ACKNOWLEDGMENT}

Acknowledgments to all the parties helping authorizers in making the research, whether assistly directly or not, and thank you to all elements who have supported it.

\section{REFERENCES}

[1] E. Robin dan M. Acuto, "Global urban policy and the geopolitics of urban data," Polit. Geogr., vol. 66, hal. 76-87, 2018.

[2] W. Lang, T. Chen, E. H. W. Chan, E. H. K. Yung, dan T. C. F. Lee, "Understanding livable dense urban form for shaping the landscape of community facilities in Hong Kong using fine-scale measurements," Cities, 2018.

[3] H. Song, M. Pan, dan Y. Chen, "Nightlife and public spaces in urban villages: A case study of the Pearl River Delta in China," Habitat Int., vol. 57, hal. 187-204, 2016.

[4] A. Madanipour, "Urban Design and Public Space," J. D. B. T.-I. E. of the S. \& B. S. (Second E. Wright, Ed. Oxford: Elsevier, 2015, hal. 789-794.

[5] R. Rusek, J. Colomer Llinas, dan J. Melendez Frigola, “A comparison study on space-use analysis techniques and proposal of a novel method for determining space needs in public facilities," Sustain. Cities Soc., vol. 39, hal. 326-334, 2018.

[6] N. Hacking dan A. Flynn, "Networks, power and knowledge in the planning system: A case study of energy from waste," Prog. Plann., vol. 113, hal. 1-37, 2017.

[7] L. Natarajan, "Socio-spatial learning: A case study of community knowledge in participatory spatial planning," Prog. Plann., vol. 111, hal. 1-23, 2017.

[8] J. Brown dan H. Tregidga, "Re-politicizing social and environmental accounting through Rancière: On the value of dissensus," Accounting, Organ. Soc., vol. 61, hal. 1-21, 2017.

[9] S. Wöll, "Feeling New York: Classless urban geographies and affective capitalist reconciliation in Horatio Alger's Ragged Dick," Emot. Sp. Soc., vol. 24, hal. 1-8, 2017.

[10] S. Koch, "International influence on forest governance in Tanzania: Analysing the role of aid experts in the REDD+ process," For. Policy Econ., vol. 83, hal. 181-190, 2017.

[11] C. Hanmer dan S. Abram, "Actors, networks, and translation hubs: Gas central heating as a rapid socio-technical transition in the United Kingdom," Energy Res. Soc. Sci., vol. 34, hal. 176$183,2017$.

[12] A. Banerjee, R. Hanna, J. Kyle, B. Olken, dan S. Sumarto, "The role of competition in effective outsourcing: Subsidized food distribution in Indonesia," J. Polit. Econ., 2017.

[13] B. L. Gilby et al., "Umbrellas can work under water: Using threatened species as indicator and management surrogates can improve coastal conservation," Estuar. Coast. Shelf Sci., vol. 199, hal. 132-140, 2017.

[14] J. M. Hatfield, "Social engineering in cybersecurity: The evolution of a concept," Comput. Secur., vol. 73, hal. 102-113, 2018.

[15] F. V. Haucke, "Smartphone-enabled social change: Evidence from the Fairphone case?," J. Clean. Prod., vol. 197, hal. 17191730, 2018.

[16] E. J. Sommerfeldt, "The civility of social capital: Public relations in the public sphere, civil society, and democracy," Public Relat. Rev., vol. 39, no. 4, hal. 280-289, 2013.

[17] C. Hutton, "The self and the 'monkey selfie': Law, integrationism and the nature of the first order/second order distinction," Lang. Sci., vol. 61, hal. 93-103, 2017.

[18] J. T. Jost, "The marketplace of ideology: 'Elective affinities' in political psychology and their implications for consumer behavior," J. Consum. Psychol., vol. 27, no. 4, hal. 502-520, 2017.

[19] R. Bellamy, J. Lezaun, dan J. Palmer, "Public perceptions of geoengineering research governance: An experimental deliberative approach," Glob. Environ. Chang., vol. 45, hal. 194202, 2017.

[20] S. Zilliox dan J. M. Smith, "Supraregulatory agreements and unconventional energy development: Learning from citizen concerns, enforceability and participation in Colorado," Extr. Ind. Soc., vol. 4, no. 1, hal. 69-77, 2017.

[21] L. J. McCunn, A. Kim, dan J. Feracor, "Reflections on a retrofit: 
Organizational commitment, perceived productivity and controllability in a building lighting project in the United States," Energy Res. Soc. Sci., vol. 38, hal. 154-164, 2018.

[22] J. Lulewicz dan A. B. Coker, "The structure of the Mississippian world: A social network approach to the organization of sociopolitical interactions," J. Anthropol. Archaeol., vol. 50, hal. 113-127, 2018

[23] J. E. Marineau, G. (Joe) Labianca, D. J. Brass, S. P. Borgatti, dan P. Vecchi, "Individuals' power and their social network accuracy: A situated cognition perspective," Soc. Networks, vol. 54, hal. 145-161, 2018

[24] P. Engelseth, "Aligning end-to-end seafood supply through a series of markets," Int. J. Prod. Econ., vol. 173, hal. 99-110, 2016.

[25] D. Faust dan D. Wolf, "Interpreting drivers of change in fluvial archives of the Western Mediterranean - A critical view," EarthScience Rev., vol. 174, hal. 53-83, 2017.

[26] N. F. Richter, S. Hauff, C. Schlaegel, S. Gudergan, C. M. Ringle, dan M. Gunkel, "Using Cultural Archetypes in Cross-cultural Management Studies," J. Int. Manag., vol. 22, no. 1, hal. 63-83, 2016.

[27] L. Nalefo, "The Role of Martabat Tujuh within the Society of the Sultanate Buton Wolio," Asian Cult. Hist., vol. 10, no. 1, hal. 6, 2017.

[28] R. T. Ridley, Zosimus: New History. Brill, 2017. 